Article

\title{
Study of Cytotoxic and Photodynamic Activities of Dyads Composed of a Zinc Phthalocyanine Appended to an Organotin
}

\author{
Isabelle Toubia ${ }^{1,2,+}$, Christophe Nguyen ${ }^{3,+}\left(\mathbb{C}\right.$, Stéphane Diring ${ }^{1}\left(\mathbb{D}\right.$, Marine Pays $^{3}$, Elodie Mattana ${ }^{3}$,

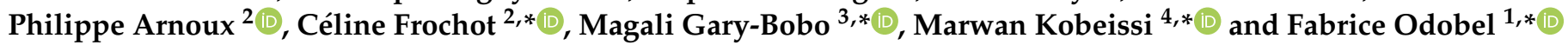 \\ 1 CEISAM, Chimie Et Interdisciplinarité, Synthèse, Analyse, Modélisation, CNRS, UMR CNRS 6230, \\ Université de Nantes, 2, rue de la Houssinière-BP 92208, CEDEX 3, 44322 Nantes, France; \\ isabelle.toubia@univ-lorraine.fr (I.T.); Stephane.Diring@univ-nantes.fr (S.D.) \\ 2 LRGP, Laboratoire Réactions et Génie des Procédés, UMR 7274 CNRS-Université de Lorraine, \\ 1 rue Grandville, 54000 Nancy, France; philippe.arnoux@univ-lorraine.fr \\ 3 IBMM, Université de Montpellier, CNRS, ENSCM, 34093 Montpellier, France; \\ christophe.nguyen@umontpellier.fr (C.N.); paysmarinepro@gmail.com (M.P.); mattana.e@gmail.com (E.M.) \\ 4 Laboratoire Rammal Rammal, Equipe de Synthèse Organique Appliquée SOA, Faculté des Sciences 5, \\ Université Libanaise, Nabatieh, Lebanon \\ * Correspondence: celine.frochot@univ-lorraine.fr (C.F.); magali.gary-bobo@inserm.fr (M.G.-B.); \\ kobeissi_marwan@hotmail.com (M.K.); Fabrice.Odobel@univ-nantes.fr (F.O.) \\ $\dagger$ These authors contributed equally to this study.
}

Citation: Toubia, I.; Nguyen, C.; Diring, S.; Pays, M.; Mattana, E.; Arnoux, P.; Frochot, C.; Gary-Bobo, M.; Kobeissi, M.; Odobel, F. Study of Cytotoxic and Photodynamic Activities of Dyads Composed of a Zinc Phthalocyanine Appended to an Organotin. Pharmaceuticals 2021, 14, 413.

https://doi.org/10.3390/ph14050413

Academic Editors: Serge Mordon and Jean Jacques Vanden Eynde

Received: 6 April 2021

Accepted: 19 April 2021

Published: 28 April 2021

Publisher's Note: MDPI stays neutral with regard to jurisdictional claims in published maps and institutional affiliations.

Copyright: (c) 2021 by the authors. Licensee MDPI, Basel, Switzerland. This article is an open access article distributed under the terms and conditions of the Creative Commons Attribution (CC BY) license (https:/ / creativecommons.org/licenses/by/ $4.0 /)$.
Abstract: The combination of photodynamic therapy and chemotherapy is a promising strategy to enhance cancer therapeutic efficacy and reduce drug resistance. In this study two zinc(II) phthalocyanine-tin(IV) conjugates linked by a triethylene glycol chain were synthesized and characterized. In these complexes, the zinc(II) phthalocyanine was used as a potential photosensitizer for PDT and the tin complex was selected as cytostatic moiety. The two dyads composed of zinc(II) phthalocyanine and tin complexes exhibited high cytotoxicity, in absence of light stimulation, against MCF-7 human breast cancer cells with low $\mathrm{LC}_{50}$ values in the range of $0.016-0.453 \mu \mathrm{M}$. In addition, these complexes showed superior cytotoxicity than their mixture of equimolar component, accompanied with a higher activity towards cancer cells compared to human healthy fibroblasts. However, under irradiation of the zinc phthalocyanine unit (at $650 \mathrm{~nm}$ ) no photodynamic activity could be detected, due to the most likely quenching of zinc(II) phthalocyanine singlet excited state by the nearby tin complex according to a photoinduced electron transfer process. This study demonstrates the potential of heterometallic anticancer chemotherapeutics composed of a zinc phthalocyanine and tin complex, and it highlights that the development of such conjugates requires that the sensitizer preserves its photophysical properties and in particular its singlet oxygen sensitization ability in the conjugate in order to combine the PDT activity with the cytotoxicity of the anticancer drug.

Keywords: photodynamic therapy; chemotherapy; zinc (II) phthalocyanine; tin complex

\section{Introduction}

Recently, there has been considerable interest in combining photodynamic therapy (PDT) with a chemotherapeutic anticancer agent [1-6]. The combination of different therapeutic approaches that acts on distinct disease pathways has shown several advantages, such as enhanced therapeutic efficacy, reduced side effects, and drug resistance problems. There are generally three approaches to combine PDT and chemotherapy, including consecutive administration of a photosensitizer and an anticancer drug, the use of their covalent and noncovalent conjugates, and co-encapsulation of these agents in a polymeric nanocarrier $[7,8]$. The combination of a photosensitizer with an appended anticancer drug, cisplatin [9,10], carboplatin [11,12], doxorubicin (DOX) [13-15], and organometallic ruthenium(II) complexes $[16,17]$ has been attempted, in order to evaluate the possibility of synergistic anticancer properties between the two entities. Interesting results were 
obtained showing an enhanced anticancer efficacy at lower drug doses [18] due to the dark chemostatic effect of the drug amplified by the PDT effect generated upon light excitation of the photosensitizer.

Tin organometallic derivatives are important classes of organometallic drugs, as they exhibit a wide spectrum of biological effects and have been widely studied as bactericides, fungicides, acaricides and wood preservatives. In addition, some compounds possess antitumor activity. The cytotoxic activity of these compounds results from the inhibition of macromolecular synthesis, the alteration of energy-producing metabolism in the mitochondria, and the reduction of DNA synthesis. In addition, the cytotoxicity induced also arises from their interaction with the cell membrane which increases the concentration of cytosolic $\mathrm{Ca}^{2+}$ and induces apoptosis. Phthalocyanines are promising second-generation photosensitizers for PDT, owing to their suitable photo-physical and photo-chemical properties, such as the strong absorption in the tissue-penetrating red visible region and high efficiency in generating singlet oxygen [19-23].

In this work, we have investigated the combination of tin complexes with a zinc phthalocyanine photosensitizer in order to take advantage of the intrinsic cytotoxicity of tin complex in the dark added to the potentially high phototoxicity of zinc phthalocyanine upon light excitation. The two entities were linked with a triethylene glycol chain, which can enhance the biocompatibility of the system (Figure 1). Although the length of this spacer might have an impact on the biological activity, this parameter was not explored in this study. Two dyads are composed of tetrasubstituted zinc phthalocyanine connected to a tin phenyl complex liganded via a malonate anchor. One tin organometallic compound bears two phenyl groups in its coordination sphere $\left(\mathrm{SnPh}_{2}\right)$, while the other is bound to three phenyls $\left(\mathrm{SnPh}_{3}\right)$. Phenyl was selected as organometallic moiety around tin(IV), because it was shown in previous studies that this type of complex gives the most potent anticancer activity [24]. The cytotoxicity of the three dyads was assessed on human healthy (fibroblasts) and cancer cell lines (MCF-7) to quantify their therapeutic potential. It was shown that the two dyads $\mathbf{Z n P c - S n P h} 2$ and $\mathbf{Z n P c - S n _ { 2 }} \mathbf{P h}_{\mathbf{6}}$ exhibit superior cytotoxicity than their equimolar mixtures of individual components and they display higher selectivity towards MCF-7 carcinoma cell line than healthy cells. On the other hand, these two dyads showed no photodynamic activity under light irradiation.

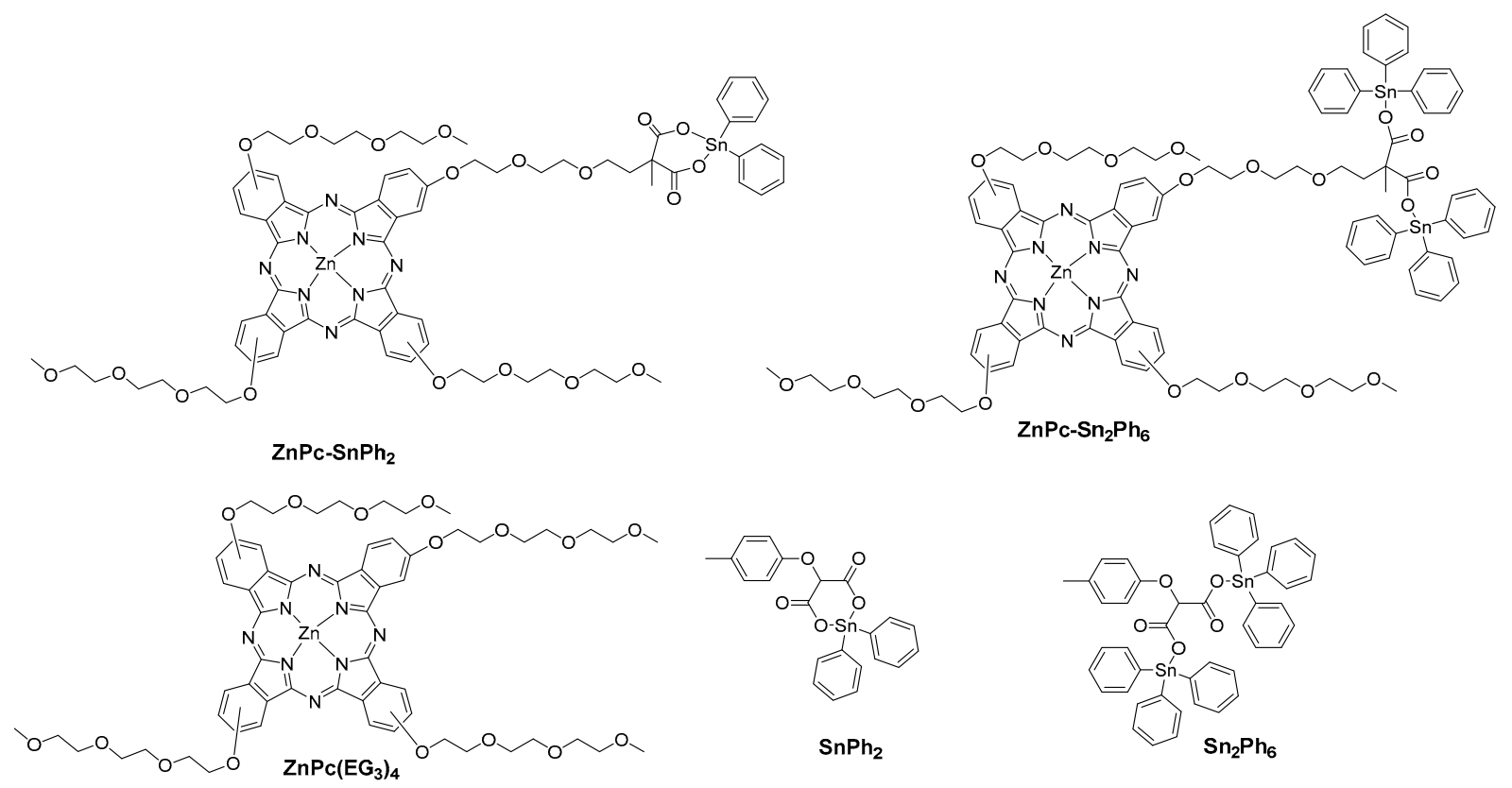

Figure 1. Structures of the compounds investigated in this study. 


\section{Results and Discussion.}

\subsection{Synthesis of the Compounds}

Scheme 1 illustrates the synthetic route used to prepare the two dyads $\mathbf{Z n P c}-\mathbf{S n P h}_{2}$ and $\mathbf{Z n P c}-\mathrm{Sn}_{2} \mathbf{P h}_{6}$. An excess of phthalonitrile $\mathbf{1}$ underwent mixed cyclisation with phthalonitrile $2^{7}$ in the presence of $\mathrm{Zn}(\mathrm{OAc})_{2} \cdot 2 \mathrm{H}_{2} \mathrm{O}$ and 1,8-diazabicyclo [5.4.0] undec-7-ene (DBU) in n-pentanol to give the « $3+1 »$ unsymmetrical phthalocyanine 3 in $18 \%$ yield (Scheme 1). The ethyl esters of the malonate were subsequently hydrolyzed with sodium hydroxide in acetone and then acidified to afford the phthalocyanine 4 with $85 \%$ yield. The introduction of tin complex was accomplished by activating the carboxylic acid group by deprotonation with triethylamine (TEA) before being reacted with the tin precursor containing two or one chloro ligands [24].
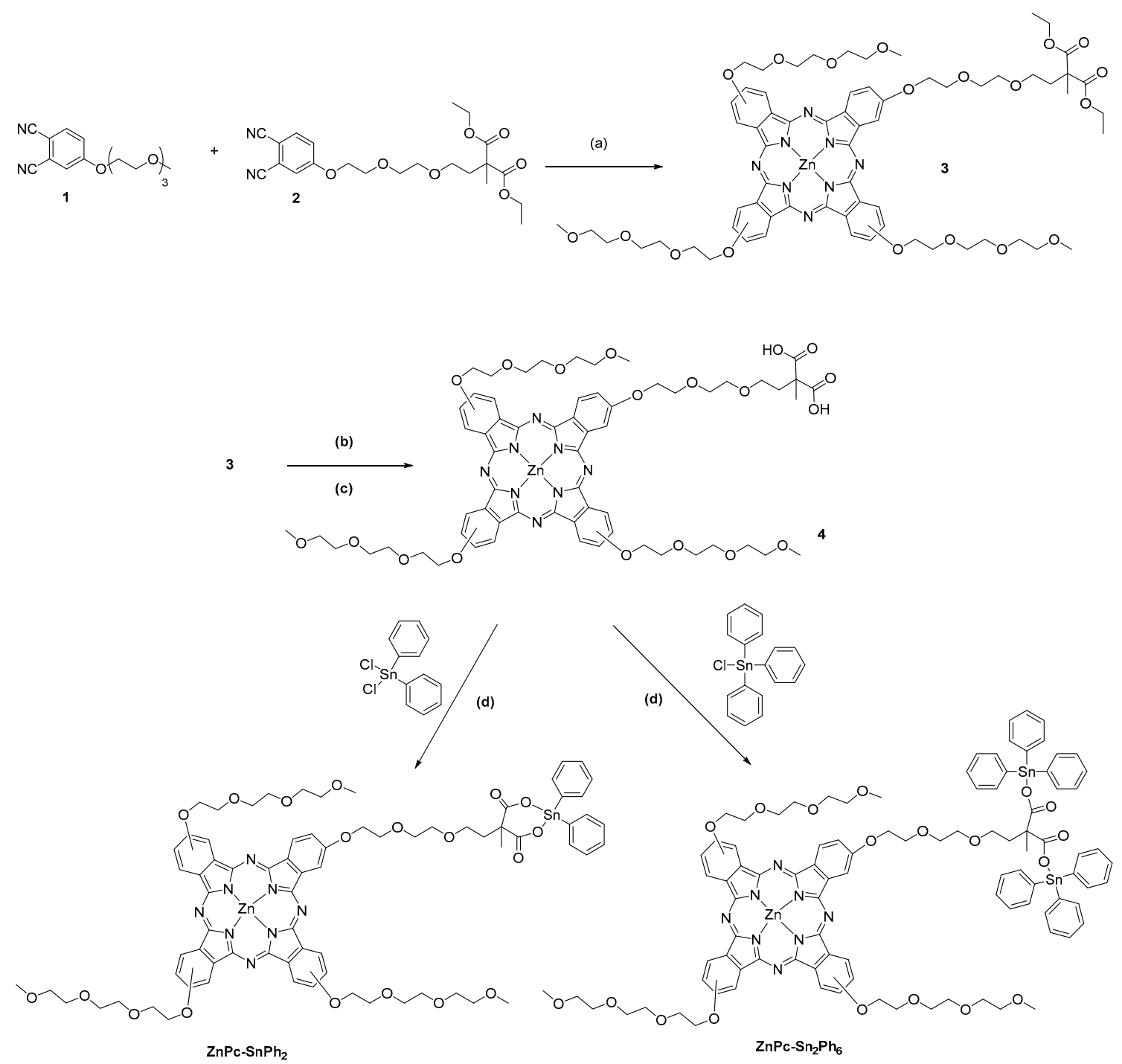

Scheme 1. Synthetic route for the preparation of the dyads composed of a zinc phthalocyanine linked to a tin complex. Reagents and conditions: (a) n-pentanol, DBU, $\mathrm{Zn}(\mathrm{OAc})_{2} .2 \mathrm{H}_{2} \mathrm{O}, 140-150{ }^{\circ} \mathrm{C}, 12 \mathrm{~h}, 18 \%$; (b) acetone, $\mathrm{NaOH}, \mathrm{reflux}, 2 \mathrm{~h}$; (c) $\mathrm{HCl}, 85 \%$; (d) THF, TEA, room temperature, $12 \mathrm{~h}, 100 \%$.

The complexes were characterized by proton NMR and elemental analysis as well as by high resolution mass spectrometry. The dyads $\mathbf{Z n P c - S n P h}, \mathbf{Z n P c - S n _ { 2 }} \mathbf{P h}_{\mathbf{6}}$ are soluble in $\mathrm{CHCl}_{3}, \mathrm{DMSO}$, THF and DMF. 


\subsection{UV-Vis Electronic Absorption Properties}

The absorption spectra of the dyads are compared with those of their components, which are displayed in Figure 2 and the spectroscopic data are gathered in Table 1. In

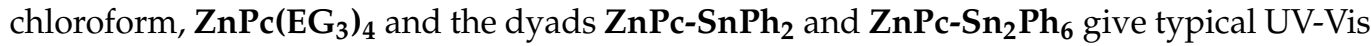
spectra of non-aggregated phthalocyanines showing intense and sharp Q-bands in the red visible region around $680 \mathrm{~nm}$ along with the less intense vibronic overtone at $616 \mathrm{~nm}$ (Figure 2A). They also displayed a Soret band at $360 \mathrm{~nm}$. The presence of the appended tin complex does not alter the spectrum of the dyads because: (i) it does not absorb beyond $300 \mathrm{~nm}$ (Supplementary Figure S1) and (ii) there is no electronic communication between the malonate group and the zinc phthalocyanine on the ground state.
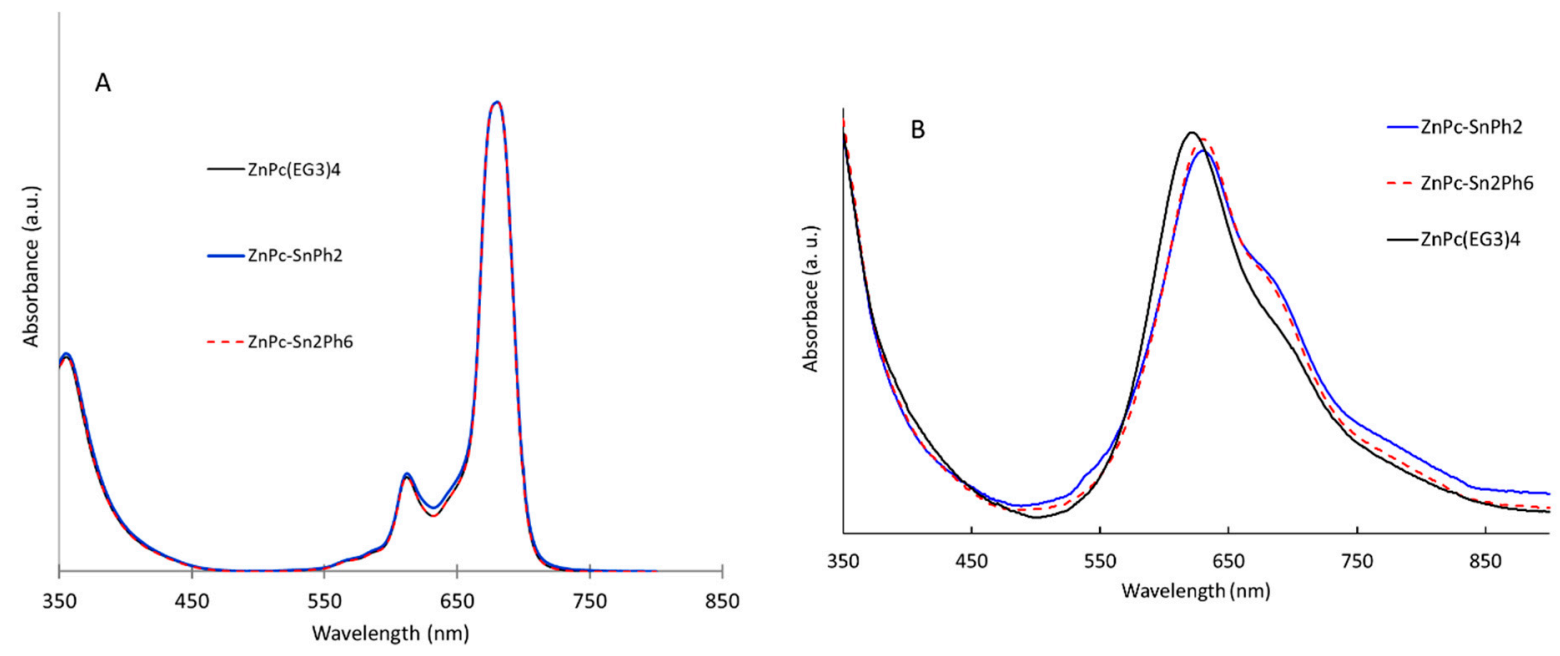

Figure 2. (A) Normalized absorption spectra of the phthalocyanine derivatives recorded in chloroform and (B) in water with $1 \%$ of DMSO at a concentration of about $10^{-6} \mathrm{M}$.

Table 1. Maximum absorption wavelengths and molar extinction coefficients of the compounds.

\begin{tabular}{|c|c|}
\hline Compounds & $\lambda_{\mathrm{abs}} / \mathrm{nm}\left(\log \epsilon / \mathbf{M}^{-1} \mathrm{~cm}^{-1}\right)$ \\
\hline $3^{a}$ & 360 (4.83); $616(4.46) ; 683(5.19)$ \\
\hline $4^{a}$ & $360(4.86) ; 616(4.48) ; 683(5.21)$ \\
\hline $\mathrm{ZnPc}\left(\mathrm{EG}_{3}\right)_{4} \mathrm{~b}$ & $351(5.45) ; 615(5.04) ; 681(5.71)$ \\
\hline $\mathrm{ZnPc} \mathrm{SnPh}_{2}{ }^{\mathrm{a}}$ & 360 (4.82); $616(4.45) ; 683$ (5.17) \\
\hline $\mathrm{ZnPc}-\mathrm{Sn}_{2} \mathrm{Ph}_{6}{ }^{\mathrm{a}}$ & $360(4.84) ; 616(4.47) ; 683(5.2)$ \\
\hline
\end{tabular}

a recorded in DMF at room temperature. ${ }^{b}$ recorded in $\mathrm{CHCl}_{3}$ at room temperature.

The spectra were also recorded in water with $1 \%$ of DMSO to approach the conditions used in biological tests (Figure 2B). The shape and the relative intensity of the Q-bands are clearly different in aqueous environment with a broadening and an inversion of the intensity of the $Q(0,0)$ and $Q(0,1)$ bands, which are located respectively around $620 \mathrm{~nm}$ and $690 \mathrm{~nm}$. This change witnesses the formation of H-aggregates. Although the solubility of the compounds is maintained in aqueous medium owing to the ethylene glycol chains, the hydrophobicity of phthalocyanine core induces the formation of $\pi$-stacked H-aggregates in aqueous environment.

\subsection{Infra-Red (IR) Spectroscopic Study}

Carboxylate ligand can chelate tin(IV) cation according to several potential binding modes (Figure 3) [25-27]. In solid state, the tin(IV) complexes are usually polymeric compounds with cis-trigonal bipyramidal geometry having five-coordinate tin sites under the bridging mode (type A). 

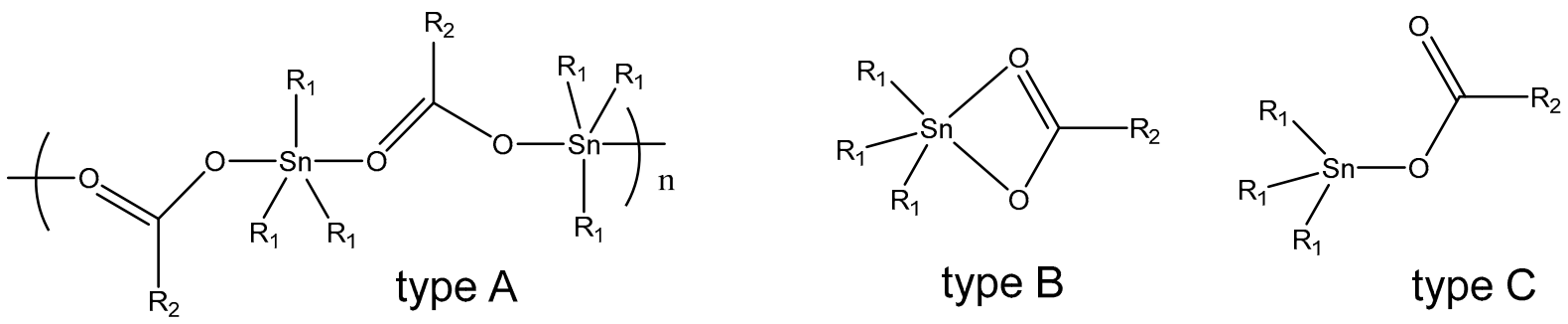

Figure 3. Illustration of three main binding modes of carboxylate ligand with tin(IV).

Particularly in solution, the complexes can exist as monomers either under a fivecoordinate chelating bridged mode (type B) or as four-coordinated tin with carboxylate acting as a monodentate ligand (type C). ATR-IR spectra can be used as tools to diagnose the mode of coordination of tin complexes [28]. More specifically, the mode of binding can be deduced by the wavenumber difference $\left(v=v_{\mathrm{as}}-v_{\mathrm{s}}\right)$ between the carboxylate antisymmetric $\left(v_{\mathrm{as}}\right)$ and symmetric $\left(v_{\mathrm{s}}\right)$ stretches. If this difference is larger than $250 \mathrm{~cm}^{-1}$, tin(IV) is involved in a tetrahedral geometry (type $C$ binding mode), while values between 250 and $150 \mathrm{~cm}^{-1}$ indicate a bridging polymeric structure (type A). When $v$ is lower than $150 \mathrm{~cm}^{-1}$, then carboxylate is bidentate and binds to $\mathrm{Sn}$ (IV) under the chelating bridged mode (type B). The strong asymmetric stretching band of the carbonyl group in the acid form of compound 4, situated at $1725 \mathrm{~cm}^{-1}$ has shrunk and is shifted to lower energy $\left(\approx 1550 \mathrm{~cm}^{-1}\right)$ after the reaction with chloro-phenyl tin derivatives, which is a clear indication that complexation of tin by the carboxylate has occurred. The wavenumber values of the stretching bands of the carboxylate before and after complexation of tin(IV) are gathered in Table 2.

Table 2. Wavenumber values of the stretching bands of the compounds recorded in the solid state by IR-ATR spectroscopy.

\begin{tabular}{|c|c|c|c|c|}
\hline Compound & $\begin{array}{c}v(\mathrm{Sn}-\mathrm{O}) \\
\mathrm{cm}^{-1}\end{array}$ & $\begin{array}{c}v_{\text {as }}(\mathrm{OCO}) \\
\mathrm{cm}^{-1}\end{array}$ & $\begin{array}{c}v_{\mathrm{s}}(\mathrm{OCO}) \\
\mathrm{cm}^{-1}\end{array}$ & $v$ \\
\hline 4 & - & 1725 & 1396 & 329 \\
\hline $\mathrm{ZnPc}-\mathrm{SnPh} \mathrm{h}_{2}$ & 452 & 1557 & 1430sh & 127 \\
\hline $\mathrm{ZnPc}-\mathrm{Sn}_{2} \mathrm{Ph}_{6}$ & 454 & 1547 & 1429 & 118 \\
\hline
\end{tabular}

For the dyads $\mathbf{Z n P c - S n P h} \mathbf{2}$ and $\mathbf{Z n P c - S n} \mathbf{P}_{\mathbf{2}} \mathbf{P h}_{\mathbf{6}}$, the $v$ values are less than $150 \mathrm{~cm}^{-1}$, which indicates that the carboxylate ligand is bidentate and binds to Sn(IV) under the chelating bridged mode.

\subsection{Fluorescence Spectroscopy}

Fluorescence spectra of the dyads $\mathbf{Z n P c}-\mathbf{S n P h}, \mathbf{Z n P c}-\mathbf{S n}_{2} \mathbf{P h}_{\mathbf{6}}$ were compared to those of the reference zinc phthalocyanine $\mathbf{Z n P c}\left(E_{3}\right)_{4}$ in order to study the possibility of a singlet excited state quenching by the tin complex. As for the electronic absorption spectra, the fluorescence emission measurements were conducted both in $\mathrm{CHCl}_{3}$ and water with $1 \%$ of DMSO (Figure 4). Whatever the solvent conditions, the fluorescence intensity of the dyads $\mathbf{Z n P c - S n P h}, \mathbf{Z n P c}-\mathbf{S n}_{2} \mathbf{P h}_{\mathbf{6}}$ decreased compare to the reference phthalocyanine $\mathrm{ZnPc}\left(\mathrm{EG}_{3}\right)_{4}$. 

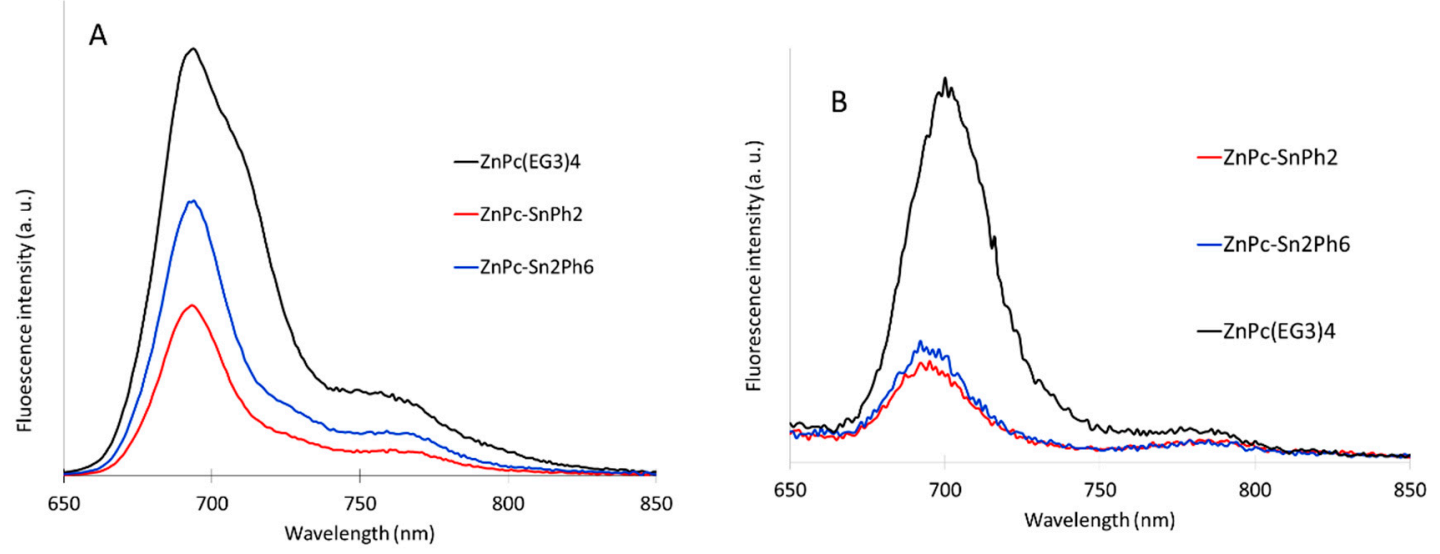

Figure 4. Fluorescence spectra of the dyads $\mathbf{Z n P c}-\mathbf{S n P h}_{2}, \mathbf{Z n P c}-\mathbf{S n}_{2} \mathbf{P h}_{\mathbf{6}}$ recorded in (A) $\mathrm{CHCl}_{3}$ or $(\mathbf{B})$ in water with $1 \%$ of DMSO and compared to the spectra of the reference phthalocyanine $\mathbf{Z n P c}\left(\mathbf{E G}_{3}\right)_{4}$ all excited at the same wavelength $\left(\lambda_{\text {exc }}=615 \mathrm{~nm}\right)$ with an iso-absorbing solution.

Based on the relative fluorescence intensities, the quenching of $\mathbf{Z n P c}-\mathrm{SnPh}_{2}$ and $\mathrm{ZnPc}-\mathrm{Sn}_{2} \mathbf{P h}_{6}$ is estimated at $60 \%$ and $36 \%$ in $\mathrm{CHCl}_{3}$ and $70 \%$ and $75 \%$ in water $+1 \%$ DMSO respectively. In aqueous medium, the fluorescence intensity is lower than in $\mathrm{CHCl}_{3}$, most probably because the $\mathrm{H}$-aggregates impart a supplementary quenching process. In addition to the formation of $\mathrm{H}$-aggregates, another fluorescence quenching process in the dyads could be attributed to photoinduced electron transfer to the tin complex (formation

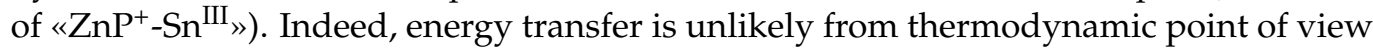
because the organo-tin complex absorbs in the deep UV, therefore its lowest energy excited state is necessarily higher than that of the singlet excited state of the zinc phthalocyanine (Supplementary Figure S1).

Overall, the fluorescence of the zinc phthalocyanine in these dyads is significantly quenched relative to that of the reference $\mathrm{ZnPc}\left(\mathrm{EG}_{3}\right)_{4}$. The fluorescence inhibition is due to the presence of tin complex and the formation of $\mathrm{H}$-aggregates, particularly in aqueous environment for the latter. The singlet excited state quenching could affect the efficiency of PDT, due to the reduction of the quantum yield of triplet excited state formation by the intervention of a competitive deactivation processes, which depopulate the singlet excited state (see below).

\subsection{Singlet Oxygen Measurements}

In order to directly estimate the impact of the tin complex on the production of singlet oxygen, the singlet oxygen quantum yield of the compounds was determined in $\mathrm{CHCl}_{3}$ and deuterated water $+1 \%$ of DMSO by recording the fluorescence intensity of singlet oxygen emission at $1270 \mathrm{~nm} . \mathrm{D}_{2} \mathrm{O}$ was chosen instead of $\mathrm{H}_{2} \mathrm{O}$ since the singlet oxygen lifetime value in $\mathrm{D}_{2} \mathrm{O}$ is higher than in $\mathrm{H}_{2} \mathrm{O}$. This is known that solvents with high vibrational frequencies are more able to quench ${ }^{1} \mathrm{O}_{2}$ [29]. The data are collected in Table 3.

Table 3. Singlet oxygen quantum yields of the compounds determined in $\mathrm{CHCl}_{3}$ and $\mathrm{D}_{2} \mathrm{O}+1 \%$ of DMSO upon excitation at $615 \mathrm{~nm}$.

\begin{tabular}{ccc}
\hline Compound & In $\mathrm{CHCl}_{\mathbf{3}}$ & In $\mathbf{D}_{\mathbf{2}} \mathbf{O}+\mathbf{1 \%}$ of DMSO \\
\hline $\mathbf{Z n P c}\left(\mathbf{E G}_{\mathbf{3}}\right)_{\mathbf{4}}$ & $0.21 \pm 0.05$ & $0 \pm 0.05$ \\
$\mathbf{Z n P c - S n P h} \mathbf{2}$ & $0.09 \pm 0.05$ & $0 \pm 0.05$ \\
${\mathbf{Z n P c}-\mathrm{Sn}_{\mathbf{2}} \mathbf{P h}_{\mathbf{6}}}$ & $0.12 \pm 0.05$ & $0 \pm 0.05$ \\
\hline
\end{tabular}

In $\mathrm{CHCl}_{3}$, the singlet oxygen quantum yield measurements reflect, within experimental errors, the degree of fluorescence quenching. Moreover, the singlet oxygen quantum yield of $\mathbf{Z n P c}\left(\mathrm{EG}_{3}\right)_{4}$ is in agreement with previously reported in DMSO [30]. In $\mathrm{D}_{2} \mathrm{O}$, 
however, the singlet oxygen emission is importantly reduced and could not be detected because the quantum yields is too low for the sensitivity of this technique. However, we cannot exclude that the singlet oxygen quantum yield of $\mathbf{Z n P c}\left(E_{3}\right)_{4}$ is not null in biological medium as the latter is quite active in PDT (see below).

\subsection{Biological Effect Analysis of $\mathbf{Z n P c}\left(E_{G_{3}}\right)_{4}$ :Cytotoxicity, PDT and ROS Production}

The cytotoxic effect of $\mathbf{Z n P c}\left(E_{3}\right)_{4}$ on human breast cancer cells (MCF-7) was determined and compared with that on healthy fibroblasts. For this, a dose-response experiment was performed by incubating cells in the darkness with increasing doses of $\mathbf{Z n P c}\left(\mathbf{E G}_{3}\right)_{4}$ for $72 \mathrm{~h}$. Then, the viability of cells was quantified and reported in Figure 5a. $\mathbf{Z n P c}\left(\mathbf{E G}_{3}\right)_{4}$ exhibited a $\mathrm{LC}_{50}$ of $16.55 \mu \mathrm{M}$ on MCF-7 cells and of $63.80 \mu \mathrm{M}$ on fibroblasts. This difference ( 4 fold) between these two cell lines demonstrated that this compound was more cytotoxic on cancer cells than healthy cells.

The photodynamic therapeutic potential was also investigated on breast cancer and healthy cells. Several concentrations of compound (from 0.01 to $0.50 \mu \mathrm{M}$ ) were tested. Cells were incubated $24 \mathrm{~h}$ with $\mathbf{Z n P c}\left(\mathbf{E G}_{3}\right)_{4}$ and submitted or not to laser excitation $(650 \mathrm{~nm}$, $20 \mathrm{~min}, 39 \mathrm{~J} . \mathrm{cm}^{-2}$ ). Two days later, the viability was quantified MCF-7 cells demonstrated a significant photosensitivity from $0.05 \mu \mathrm{M}$ of $\mathbf{Z n P c}\left(\mathbf{E G}_{3}\right)_{4}$ (Figure $5 b$ ). Indeed, cells submitted to laser excitation exhibited $31 \%$ cell death. This PDT effect increased in accordance with increasing concentration of $\mathbf{Z n P c}\left(E_{3}\right)_{4}$ to reach $92 \%$ cell death when cells were incubated with $0.50 \mu \mathrm{M}$ of $\mathbf{Z n P c}\left(E_{3}\right)_{4}$ and submitted to photoexcitation. This effect is very strong and indicates that the reference compound $\mathbf{Z n P c}\left(\mathbf{E G}_{3}\right)_{4}$ is quite active in PDT, most reasonably upon production of singlet oxygen. We also investigated this PDT efficiency on healthy cells in order to verify if the discriminatory effect already observed on dark cytotoxicity (Figure 5c) could be reproduced under laser excitation. Unfortunately, this effect is about the same on cancer or healthy cells, with a significant effect from $0.05 \mu \mathrm{M}$ and a high PDT efficiency at $0.50 \mu \mathrm{M}$. However, we could note a difference between the two cell lines at this concentration; indeed, only $8 \%$ of cancer cells survived when $28 \%$ of fibroblasts survived after irradiation.

To identify the phototoxicity mechanism involved here, ROS quantification was performed and reported in Figure $5 \mathrm{~d}$. Cells were incubated with $\mathrm{DCFH}_{2}-\mathrm{DA}\left(2^{\prime}, 7^{\prime}\right.$ dichlorodihydrofluorescein diacetate), which is a non-fluorescent molecule. In the presence of ROS this molecule is oxidized into the fluorescent $2^{\prime}, 7^{\prime}$-dichlorodihydrofluorescein (DCF), whose green luminescence can be detected using a fluorescence microscope. The results showed that in the presence of $0.50 \mu \mathrm{M}$ of $\mathbf{Z n P c}\left(\mathbf{E G}_{3}\right)_{4}$, light excitation at a wavelength of $650 \mathrm{~nm}$ induced green fluorescence inside the cells, mainly on cancer cells but also on healthy cells, thus demonstrating ROS production and confirming cell death induced by PDT effect.

Altogether these data demonstrated that this compound is very efficient for dark cytotoxicity and overall for PDT action, but it is not really discriminant between cancer and healthy cells. Although often, the main limitation of cancer therapy is the poor selectivity of cancer cells inducing a large panel of secondary effects on healthy organs and cells. So we decided to graft organotin complex on $\mathbf{Z n P c}\left(E_{3}\right)_{4}$ to improve the effect and the selectivity on cancer cells. 
(a)

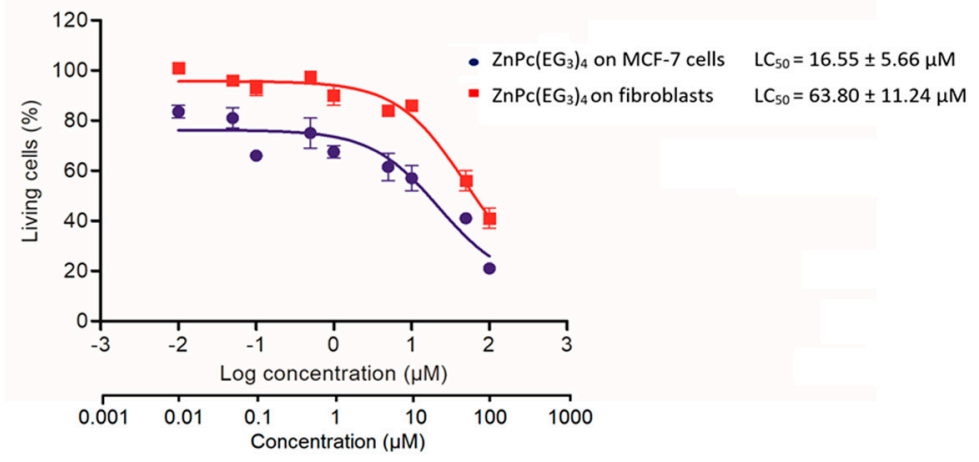

(b)

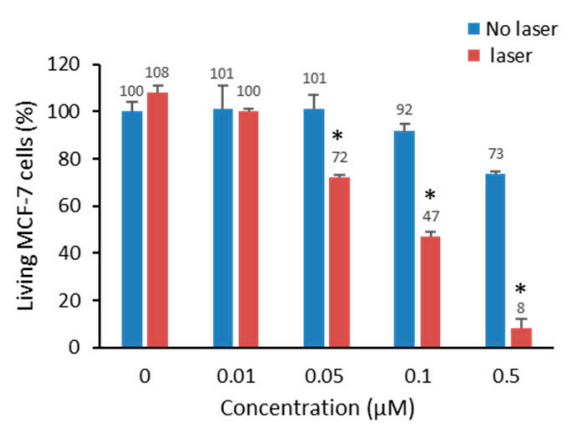

(c)

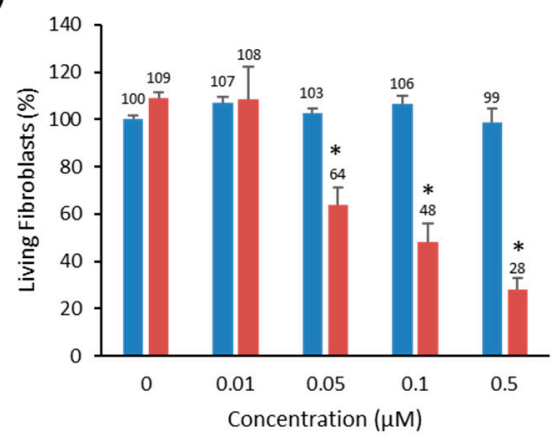

(d)

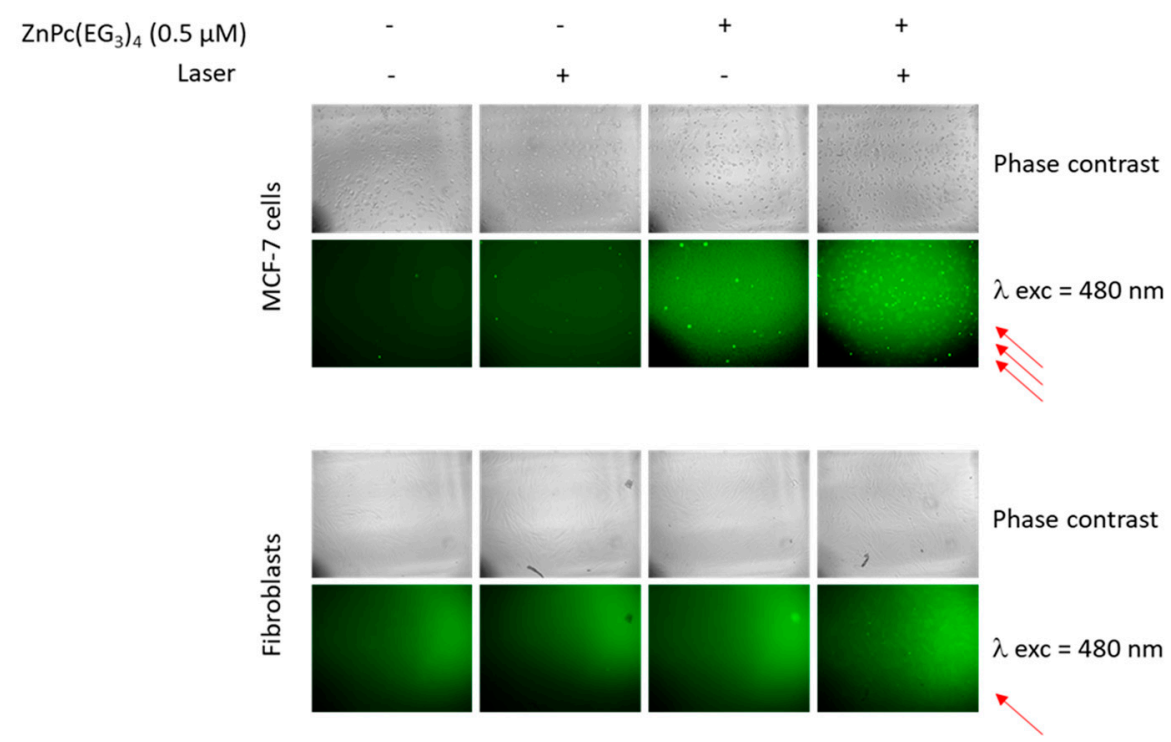

Figure 5. (a) Cytotoxicity measurement of increasing concentrations of $\mathrm{ZnPc}\left(\mathrm{EG}_{3}\right)_{4}$. Dose-responses on cancer MCF-7 cells and healthy fibroblasts incubated $72 \mathrm{~h}$ with $\mathbf{Z n P c}\left(\mathrm{EG}_{3}\right)_{4}$. (b) Phototoxicity of the compound $\mathrm{ZnPc}\left(\mathrm{EG}_{3}\right)_{4}$ incubated at increasing concentrations (from 0.01 to $0.50 \mu \mathrm{M}$ ) with cancer cells MCF-7 or (c) healthy fibroblasts for $24 \mathrm{~h}$ and then irradiated $\left(20 \mathrm{~min}, \lambda_{\mathrm{exc}}=650 \mathrm{~nm}, 39 \mathrm{~J} . \mathrm{cm}^{-2}\right) .{ }^{*} p<0.05$ statistically different from "No laser". The bar graph corresponds to the mean \pm standard deviation of the values of 2 independent experiments in triplicate. (d) Demonstration of ROS production in cells (highlighted by red arrows) incubated for $24 \mathrm{~h}$ with $0.50 \mu \mathrm{M}$ of $\mathrm{ZnPc}\left(\mathrm{EG}_{3}\right)_{4}$, then incubated with $\mathrm{DCFH}_{2}$-DA $(20 \mu \mathrm{M}, 45 \mathrm{~min})$ and irradiated for $10 \mathrm{~min}$ at $650 \mathrm{~nm}$. The green fluorescence inside the cells reflects ROS production (imaged at $480 \mathrm{~nm}$ ). 


\subsection{Cytotoxic Potential Analysis of the Dyads $\mathbf{Z n P c - S n P h}$ and $\mathbf{Z n P c - S n _ { 2 }} \mathbf{P h}_{6}$ on Cancer and Healthy Cells}

In order to determine the therapeutic potential of these new compounds, the cytotoxic activity on MCF-7 cells and also on healthy fibroblasts was studied. Towards this goal, the cells were incubated $72 \mathrm{~h}$ in darkness, with increasing concentrations of each compound (from 0.01 to $100 \mu \mathrm{M}$ ). Drug concentrations leading to $50 \%$ cell mortality $\left(\mathrm{LC}_{50}\right.$ ) were determined using the classical sigmoidal dose-response curves of cytotoxicity obtained when plotted as a logarithmic function of the concentration $(\mu \mathrm{M})$.

The analysis of the curves in Figure 6, shows that the compound $\mathbf{Z n P c - S n _ { 2 }} \mathbf{P h}_{6}$ is about 30 times more toxic on MCF-7 cells $\left(\mathrm{LC}_{50}=0.016 \mu \mathrm{M}\right)$ than the compound $\mathbf{Z n P c}-\mathbf{S n P h}_{2}$ $\left(\mathrm{LC}_{50}=0.453 \mu \mathrm{M}\right)$. It is also interesting to note that both tin dyads present a higher toxicity on cancer cells compared to healthy cells (Figure 6). Indeed, the $\mathrm{LC}_{50}$ are lower on cancer cells than on fibroblasts with $\mathrm{LC}_{50}$ of 0.016 vs. $0.032 \mu \mathrm{M}$ for the compound $\mathbf{Z n P c}-\mathbf{S n}_{2} \mathbf{P h}_{6}$, and $\mathrm{LC}_{50}$ of 0.453 and 0.513 for the compound $\mathbf{Z n P c - S n P h}$. These results suggest that the $\mathrm{ZnPc}-\mathrm{SnPh}_{2}$ dyad may be a potentially interesting basis to develop targeting cancer cells.
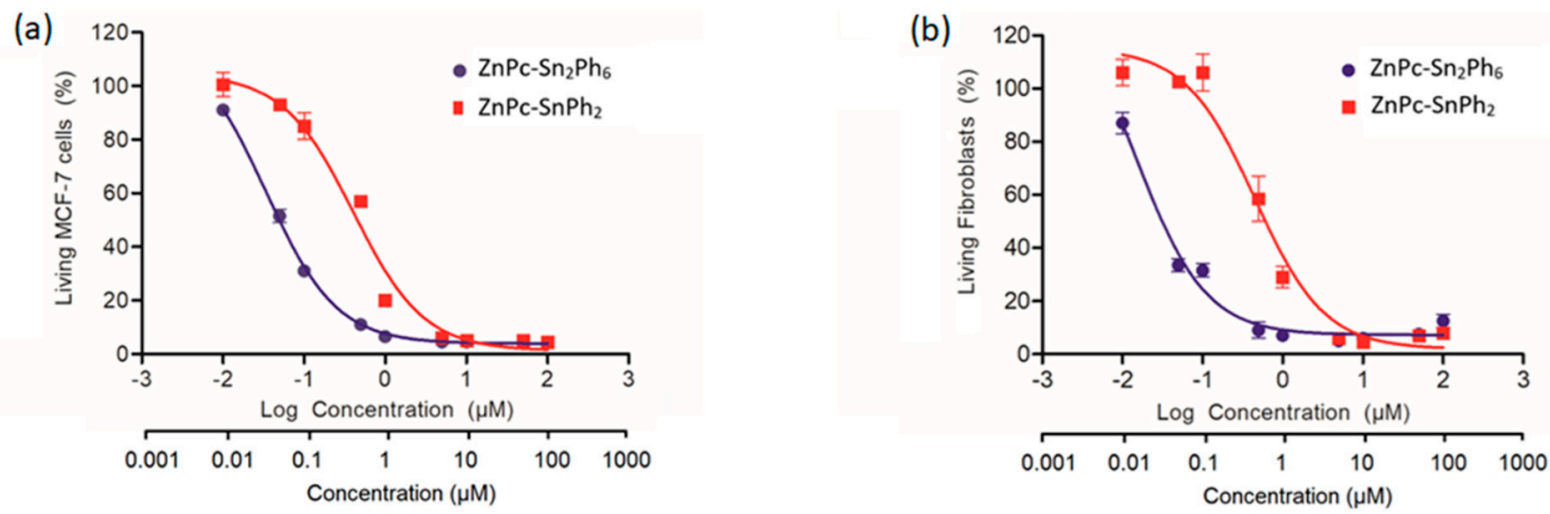

(c)

\begin{tabular}{|c|c|c|}
\hline Compounds & $\begin{array}{c}\mathrm{LC}_{50}(\mu \mathrm{M}) \\
\mathrm{MCF}-7\end{array}$ & $\begin{array}{l}\mathrm{LC}_{50}(\mu \mathrm{M}) \\
\text { Fibroblast }\end{array}$ \\
\hline $\mathrm{ZnPc}-\mathrm{SnPh}_{2}$ & $0.453 \pm 0.028$ & $0.513 \pm 0.133$ \\
\hline $\mathrm{ZnPc}-\mathrm{Sn}_{2} \mathrm{Ph}_{6}$ & $0.016 \pm 0.002$ & $0.032 \pm 0.001$ \\
\hline
\end{tabular}

Figure 6. Cytotoxic study of $\mathbf{Z n P c - S n P h} 2$ and $\mathrm{ZnPc}_{\mathbf{2}} \mathrm{Sn}_{2} \mathrm{Ph}_{6}$. (a) MCF-7 cells and (b) healthy fibroblasts were incubated $72 \mathrm{~h}$ with increasing concentrations of $\mathbf{Z n P c}-\mathbf{S n P h}_{\mathbf{2}}$ and $\mathbf{Z n P c - S n _ { 2 }} \mathbf{P h}_{\mathbf{6}}$, and maintained in darkness. (c) LC 50 values are reported for each cell line. Values are means \pm standard deviation of 2 experiments in triplicate.

In order to confirm the therapeutic interest of using a dyad rather than its constituents, we compared the cytotoxicity of tin dyads to the cytotoxic effect of equimolar mixtures of the phthalocyanine $\mathbf{Z n P c}\left(\mathbf{E G}_{3}\right)_{4}$ and $\mathbf{S n P h} \mathbf{P h}_{2}$ or $\mathbf{S n}_{2} \mathbf{P h}_{\mathbf{6}}$ (Figure 7). For all conditions tested here, and as reported in the Figure 7e, the cytotoxicity induced by dyads is always higher than the equimolar mixture of their constituents. 
(a)

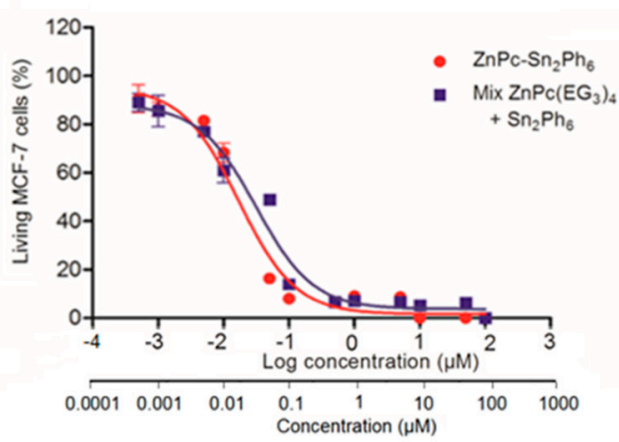

(c)

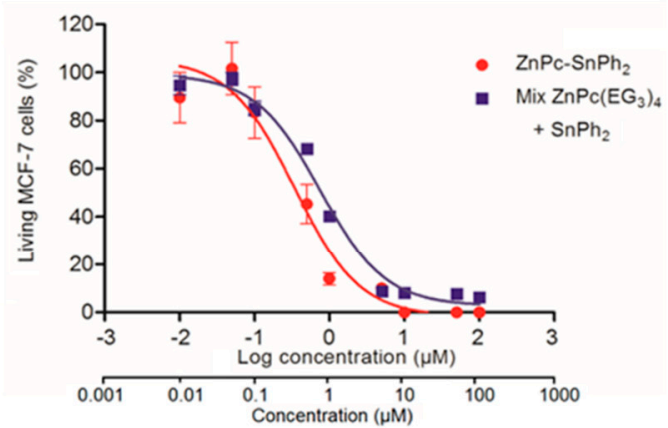

(b)

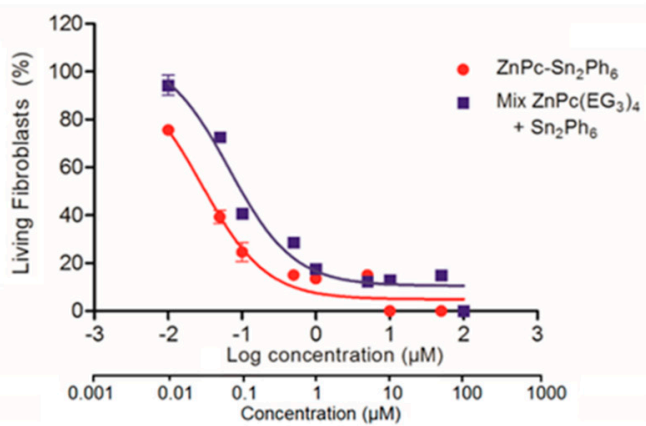

(d)

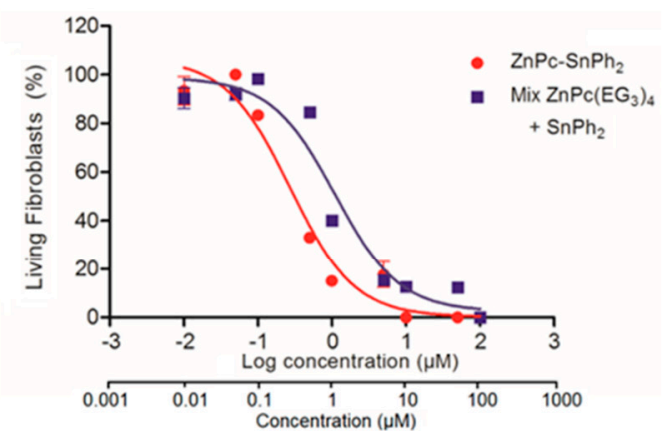

(e)

\begin{tabular}{|c|c|c|}
\hline Compounds & $\begin{array}{c}\mathrm{LC} \\
\text { MCF-7 }\end{array}$ & $\begin{array}{c}\mathrm{LC}_{50}(\mu \mathrm{M}) \\
\text { Fibroblast }\end{array}$ \\
\hline $\mathrm{ZnPc}-\mathrm{Sn}_{2} \mathrm{Ph}_{6}$ & $0.016 \pm 0.002$ & $0.032 \pm 0.001$ \\
\hline $\mathrm{Mix} \mathrm{ZnPc}\left(\mathrm{EG}_{3}\right)_{4}+\mathrm{Sn}_{2} \mathrm{Ph}_{6}$ & $0.025 \pm 0.002$ & $0.097 \pm 0.008$ \\
\hline $\mathrm{ZnPC}-\mathrm{SnPh}_{2}$ & $0.453 \pm 0.028$ & $0.513 \pm 0.133$ \\
\hline $\mathrm{Mix} \mathrm{ZnPc}\left(\mathrm{EG}_{3}\right)_{4}+\mathrm{SnPh}_{2}$ & $0.755 \pm 0.109$ & $1.224 \pm 0.036$ \\
\hline
\end{tabular}

Figure 7. Study of the comparative cytotoxicity of the tin dyads with the equimolar mixture of their constituents, tin and zinc phthalocyanine. Comparison of the cytotoxic efficiency of the compound $\mathbf{Z n P c}-\mathrm{Sn}_{2} \mathrm{Ph}_{6}$ and the mixture $\mathbf{Z n P c}\left(\mathrm{EG}_{3}\right)_{4}$ $+\mathbf{S n}_{2} \mathbf{P h}_{6}$ (a) on MCF-7 cells and (b) on healthy fibroblasts. Comparison of the cytotoxic efficiency of the compound $\mathrm{ZnPc}-\mathrm{SnPh}_{2}$ and the mixture $\mathbf{Z n P c}\left(\mathrm{EG}_{3}\right)_{4}+\mathbf{S n P h}_{2}$ (c) on MCF-7 cells and (d) on healthy fibroblasts. Cells were incubated during $72 \mathrm{~h}$ with increasing concentrations of the dyads or the mixture (Mix) and maintained in darkness. (e) $\mathrm{LC}_{50}$ values are reported for each cell line. Values are means \pm standard deviation of 2 experiments in triplicate.

\subsection{Photodynamic Therapy Investigations of Dyads}

The PDT efficiency was first studied on cancer cells with the dyads $\mathbf{Z n P c - S n _ { 2 }} \mathbf{P h}_{\mathbf{6}}$ and $\mathrm{ZnPc}_{\mathrm{SnPh}}$ under laser excitation of the zinc phthalocyanine in its Q-band at $650 \mathrm{~nm}$. Experiments were performed at the concentration of $\mathrm{LC}_{50}$ and below up to a factor of 10 . Several concentrations were tested, as reported in the tables below, (Tables 4 and 5) but unfortunately no specific mortality due to the laser was obtained under these conditions. This result can be explained by fluorescence quenching of the zinc phthalocyanine in these dyads, which most probably inhibits the energy transfer process to oxygen. 
Table 4. Values of cellular survival in \% corresponding to the mean \pm standard deviation of 2 independent experiments conducted in duplicate.

\begin{tabular}{|c|c|c|c|c|}
\hline MCF-7 with ZnPc-Sn ${ }_{2} \mathrm{Ph}_{6}$ (in $\left.\mu \mathrm{M}\right)$ & 0 & 0.005 & 0.01 & 0.05 \\
\hline$\%$ cell survival, in dark & $100 \pm 2$ & $99 \pm 3$ & $77 \pm 2$ & $38 \pm 3$ \\
\hline$\%$ cell survival, $\lambda_{\text {exc }}=650 \mathrm{~nm}$ & $98 \pm 1$ & $98 \pm 4$ & $75 \pm 3$ & $41 \pm 3$ \\
\hline
\end{tabular}

Table 5. Values of cellular survival in \% corresponding to the mean \pm standard deviation of 2 independent experiments conducted in duplicate.

\begin{tabular}{ccccc}
\hline MCF-7 with ZnPc-SnPh (in $\boldsymbol{\mu M})$ & $\mathbf{0}$ & $\mathbf{0 . 0 5}$ & $\mathbf{0 . 1}$ & $\mathbf{0 . 5}$ \\
\hline \% cell survival, in dark & $100 \pm 5$ & $92 \pm 3$ & $88 \pm 4$ & $38 \pm 5$ \\
\% cell survival, $\lambda_{\text {exc }}=650 \mathrm{~nm}$ & $90 \pm 9$ & $90 \pm 4$ & $80 \pm 2$ & $36 \pm 2$ \\
\hline
\end{tabular}

Another series of experiments was carried out under light excitation 390/420 nm, on MCF-7 cells and also on healthy fibroblasts. Again, no effect could be observed.

Taken together, these results show that these two dyads have a cytotoxic effect on cells and would allow cancer cells to be targeted more effectively than healthy cells. However, they did not show efficacy in PDT under all of the conditions tested most probably because the singlet excited state is quenched by the appended tin complex, that inhibits singlet oxygen production.

\section{Materials and Methods}

\subsection{Synthesis of the Compounds}

Generalities

${ }^{1} \mathrm{H}$ and ${ }^{13} \mathrm{C}$ NMR spectra were recorded on an AVANCE 300 UltraShield BRUKER and AVANCE 400 BRUKER. Chemical shifts for ${ }^{1} \mathrm{H}$ NMR spectra are referenced relative to residual proton in the deuterated solvent $\left(\mathrm{CDCl}_{3} \delta=7.26 \mathrm{ppm}\right.$ for ${ }^{1} \mathrm{H}, \mathrm{DMSO}-\mathrm{d}_{6} \delta=2.50 \mathrm{ppm}$ for ${ }^{1} \mathrm{H}, \mathrm{THF}-\mathrm{d}_{8} \delta=3.57,1.72 \mathrm{ppm}$ for ${ }^{1} \mathrm{H}$ ) or to an internal reference (TMS, $\delta=0 \mathrm{ppm}$ for both ${ }^{1} \mathrm{H}$ and ${ }^{13} \mathrm{C}$ ). NMR spectra were recorded at room temperature, chemical shifts are written in ppm and coupling constants in Hz. High-resolution mass (HR-MS) spectra were obtained by electrospray ionization coupled with high resolution ion trap orbitrap (LTQ-Orbitrap, ThermoFisher Scientific), working in ion-positive or ion-negative mode. UVvisible absorption spectra were recorded on a Variant Cary 300, using $1 \mathrm{~cm}$ path length cells. Emission spectra were recorded on a Fluoromax-4 Horiba Jobin Yvon spectrofluorometer (1 cm quartz cells).

Chemicals were purchased from Sigma-Aldrich or Alfa Aesar and used as received. $\mathrm{CHCl}_{3}$ is stabilized with EtOH. Thin-layer chromatography (TLC) was performed on silica sheets precoated with Merck 5735 Kieselgel $60 \mathrm{~F}_{254}$. Column chromatography was carried out with Merck 5735 Kieselgel 60F (0.040-0.063 mm mesh). Reference ZnPc(EG (E) $_{4}$ was synthesized according to literature [30].

Phthalocyanine 3. A mixture of $266 \mathrm{mg}$ (1.52 mmol), phthalonitrile $13.1 \mathrm{~g}$ (10.68 mmol) and $\mathrm{Zn}(\mathrm{OAc})_{2} \cdot 2 \mathrm{H}_{2} \mathrm{O} 83 \mathrm{mg}(3.81 \mathrm{mmol})$ in n-pentanol $(25 \mathrm{~mL})$ was heated to $100^{\circ} \mathrm{C}$, and a small amount of DBU $(0.9 \mathrm{~mL})$ was subsequently added. The mixture was heated at $150{ }^{\circ} \mathrm{C}$ for $12 \mathrm{~h}$. After cooling the volatiles were removed under reduced pressure. The residue was dissolved in $\mathrm{CHCl}_{3}$ and a part of the symmetrical phthalocyanine was separated from the desired compound by flash chromatography using $\mathrm{CHCl}_{3} / \mathrm{MeOH}(98: 2 v / v)$ as the eluent. The product was further purified by preparative TLC using the same eluent as before to give a blue green oily compound. Yield: (360 mg, 18\%). UV-Vis (DMF, nm) $\lambda_{\max }$ $\left(\log \epsilon / \mathrm{M}^{-1} \mathrm{~cm}^{-1}\right): 360$ (4.83); 616 (4.46); 683 (5.19). ${ }^{1} \mathrm{H} \mathrm{NMR}\left(\mathrm{CDCl}_{3}, 300 \mathrm{MHz}\right) \delta(\mathrm{ppm})$ : $9.12(\mathrm{br}, 4 \mathrm{H}), 8.68(\mathrm{~s}, 4 \mathrm{H}), 7.61(\mathrm{br}, 4 \mathrm{H}), 4.66(\mathrm{br}, 8 \mathrm{H}), 4.16-4.06(\mathrm{~m}, 12 \mathrm{H}), 3.91-3.90(\mathrm{~m}, 6 \mathrm{H})$, $3.84-3.83(\mathrm{t}, 2 \mathrm{H}, J=4.95 \mathrm{~Hz}), 3.81-3.78(\mathrm{~m}, 6 \mathrm{H}), 3.73-3.66(\mathrm{~m}, 8 \mathrm{H}), 3.62-3.56(\mathrm{~m}, 8 \mathrm{H}), 3.37(\mathrm{~s}$, $9 \mathrm{H}), 2.26-2.22(\mathrm{t}, 2 \mathrm{H}, J=6.98 \mathrm{~Hz}), 1.45(\mathrm{~s}, 3 \mathrm{H}), 1.24-1.18(\mathrm{tt}, 6 \mathrm{H}, J=1.56,7.34 \mathrm{~Hz})$. HRMS 
$(\mathrm{ES}+)[\mathrm{M}+\mathrm{H}]^{+} \mathrm{m} / \mathrm{z} 1367.5042$ found, 1367.5066 calc. Elem. Anal. Exp C, 58.97; H, 6.47; N, 7.74. calc C, 58.59; H, 6.1; N, 8.11.

Phthalocyanine 4. A mixture of $370 \mathrm{mg}\left(5 \times 10^{-2} \mathrm{mmol}\right)$, $\mathrm{NaOH} 18 \mathrm{mg}\left(45 \times 10^{-2} \mathrm{mmol}\right)$, and acetone $(8 \mathrm{~mL})$ was heated under reflux for $2 \mathrm{~h}$. The volatiles were removed under reduced pressure. The green residue was washed thoroughly with acetone, and then redissolved in water and acidified with $3 \mathrm{M} \mathrm{HCl}$ until $\mathrm{pH}=4$. The green precipitate was washed thoroughly with water and ethanol, and then dried under vacuum. Yield: (57 mg, 85\%). UV-Vis (DMF, nm) $\lambda_{\max }\left(\log \epsilon / \mathrm{M}^{-1} \mathrm{~cm}^{-1}\right): 360$ (4.86); 616 (4.48); 683 (5.21). ${ }^{1} \mathrm{H}$ NMR (DMSO-d 6 with a trace amount of pyridine, $\left.300 \mathrm{MHz}\right) \delta(\mathrm{ppm}): 9.29-9.24(\mathrm{~m}, 4 \mathrm{H})$, 8.93-8.88 (m, 4H), 7.79-7.75 (m, 4H), 4.68-4.63 (br, 8H), 4.07-4.04 (br, 8H), 3.64-3.66 (m, $10 \mathrm{H}), 3.57-3.52(\mathrm{~m}, 12 \mathrm{H}), 3.42-3.40(\mathrm{t}, 8 \mathrm{H}, \mathrm{J}=6.06 \mathrm{~Hz}), 3.23(\mathrm{~s}, 9 \mathrm{H}), 2.23-2.20(2 \mathrm{H}, \mathrm{m}), 1.36$ (s, 3H). HRMS (ES-) [M-H] m/z 1309.4309 found, 1309.4238 calc. Elem. Anal. Exp C, 54.4; $\mathrm{H}, 5.52 ; \mathrm{N}, 7.95$. calc C, 54.82; H, 5.95; N, 8.12.

$\mathrm{ZnPc}_{\mathrm{SnPh}}$. A solution of phthalocyanine $435 \mathrm{mg}\left(2.6 \times 10^{-2} \mathrm{mmol}\right)$ in $\mathrm{THF}$ $(1 \mathrm{~mL})$ was added dropwise to a solution of $\mathrm{SnPh}_{2} \mathrm{Cl}_{2} 9 \mathrm{mg}\left(2.6 \times 10^{-2} \mathrm{mmol}\right)$ in THF $(1 \mathrm{~mL})$ at room temperature. The reaction was stirred for $20 \mathrm{~min}$, subsequently $\mathrm{NEt}_{3} 8 \mu \mathrm{L}$ $\left(5.3 \times 10^{-2} \mathrm{mmol}\right)$ was added dropwise. The reaction was then stirred overnight. The solvent was evaporated and the residue was washed with water and dried in vacuum. Yield: (42 mg, 100\%). UV-Vis (DMF, nm) $\lambda_{\max }\left(\log \epsilon / \mathrm{M}^{-1} \mathrm{~cm}^{-1}\right)$ : 360 (4.82); 616 (4.45); 683 (5.17). ${ }^{1} \mathrm{H}$ NMR (THF-d $\left.8,400 \mathrm{MHz}\right) \delta$ (ppm): 9.26-9.24 (br, 4H), 8.90 (br, 4H), 7.77-7.72 $(\mathrm{m}, 8 \mathrm{H}), 7.45-7.37(\mathrm{~m}, 6 \mathrm{H}), 4.68-4.66(\mathrm{t}, 8 \mathrm{H}, J=4.71 \mathrm{~Hz}), 4.12-4.10(\mathrm{t}, 8 \mathrm{H}, J=4.48 \mathrm{~Hz})$, $3.84-3.82(\mathrm{t}, 8 \mathrm{H}, J=5.17 \mathrm{~Hz}), 3.75-3.71(\mathrm{~m}, 8 \mathrm{H}), 3.67-3.64(\mathrm{t}, 8 \mathrm{H}, J=4.82 \mathrm{~Hz}), 3.52-3.50(\mathrm{~m}$, $8 \mathrm{H}), 3.31(\mathrm{~s}, 9 \mathrm{H}), 1.28(\mathrm{~s}, 3 \mathrm{H})$. HRMS (ES+) $[\mathrm{M}+\mathrm{H}]^{+} \mathrm{m} / \mathrm{z} 1583.4023$ found, 1583.4088 calc. Elem. Anal. Exp C, 51.43; H, 5.82; N, 6.63. calc C, 51.63; H, 5.77; N, 6.42 .

$\mathbf{Z n P c}-\mathbf{S n}_{\mathbf{2}} \mathbf{P h}_{\mathbf{6}}$. A solution of phthalocyanine $433 \mathrm{mg}\left(2.5 \times 10^{-2} \mathrm{mmol}\right)$ in THF $(1 \mathrm{~mL})$ was added dropwise to a solution of $\mathrm{SnPh}_{3} \mathrm{Cl} 19 \mathrm{mg}\left(5 \times 10^{-2} \mathrm{mmol}\right)$ in THF $(1 \mathrm{~mL})$ at room temperature. The reaction was stirred for $20 \mathrm{~min}$, subsequently $\mathrm{NEt}_{3} 7 \mu \mathrm{L}\left(5 \times 10^{-2}\right.$ mmol) was added dropwise. The reaction was then stirred overnight. The solvent was evaporated and the residue was washed with water and dried in vacuum. Yield: (50 mg, 100\%). UV-Vis (DMF, nm) $\lambda_{\max }\left(\log \epsilon / \mathrm{M}^{-1} \mathrm{~cm}^{-1}\right): 360$ (4.84); 616 (4.47); 683 (5.2). ${ }^{1} \mathrm{H}$ NMR (DMSO-d $\mathrm{d}_{6}$ with a trace amount of pyridine, $\left.300 \mathrm{MHz}\right) \delta(\mathrm{ppm})$ : 9.05-9.04 (br, 4H), 8.66-8.61 (br, 4H), 7.85-7.82 (br, 6H), 7.71-7.64 (br, 6H), 7.43-7.41 (br, 9H), 7.28 (br, 13H), 4.64-4.62 (br, 8H), 4.08 (br, 8H), 3.82-3.79 (br, 6H), 3.71-3.69 (br, 8H), 3.63-3.62 (br, 8H), 3.51-3.48 $(\mathrm{t}, 8 \mathrm{H}, \mathrm{J}=4.88 \mathrm{~Hz}), 3.26(\mathrm{~s}, 9 \mathrm{H}), 1.19(\mathrm{~s}, 3 \mathrm{H})$. HRMS (ES+) $[\mathrm{M}+\mathrm{H}]^{+} \mathrm{m} / \mathrm{z} 2011.4662$ found, 2011.4675 calc. Elem. Anal. Exp C, 57.28; H, 6.12; N, 5.54. calc C, 57.37; H, 5.88; N, 5.78 .

\subsection{Biological Experiments \\ 3.2.1. Cell Culture}

Human breast adenocarcinoma cells (MCF-7) (purchased from ATCC) were cultured in Dulbecco Eagle's Minimal Essential Medium (DMEM) supplemented with 10\% fetal bovine serum (FBS) and 1\% penicillin/streptomycin (P/S). Adult Human Dermal Fibroblast cells (FS 20-68) were maintained in Roswell Park Memorial Institute (RPMI) medium supplemented with 10\% FBS and 1\% P/S. Both cell lines were allowed to grow in humidified atmosphere at $37^{\circ} \mathrm{C}$ under $5 \% \mathrm{CO}_{2}$. For cytotoxic studies, the compounds (powder) were first diluted in DMSO at the concentration of $10 \mathrm{mM}$. Then, they were sonicated during $30 \mathrm{~s}$ and diluted at the required concentrations in culture medium of each cell line.

\subsubsection{Cytotoxicity Study}

MCF-7 and fibroblasts (FS 20-68) cells were seeded into 96-well plates at a density of 1000 cells $\mathrm{cm}^{-2}$. One day after cell growth, cells were incubated with or without different concentrations of compounds (from 0.01 to $100 \mu \mathrm{M}$ ) for 3 days. To quantify the percentage of living cells in each condition, cells were incubated $4 \mathrm{~h}$ with $0.5 \mathrm{mg} \cdot \mathrm{mL}^{-1}$ MTT (3-(4, 5-dimethylthiazol-2-yl)-2,5-diphenyltetrazoliumbromide) in order to determine 
mitochondrial enzyme activity. Then, MTT precipitates were dissolved in ethanol/DMSO $(1: 1)$ solution and absorbance was measured at $540 \mathrm{~nm}$.

\subsubsection{Phototoxicity Assay at $650 \mathrm{~nm}$}

MCF-7 cancer cells were seeded into 96-well plates at a concentration of 1000 cells per well in $100 \mu \mathrm{L}$ of culture medium and allowed to grow for $24 \mathrm{~h}$. Then, cells were incubated $24 \mathrm{~h}$, with or without various concentrations of compound solutions. After incubation, cells were submitted or not to laser irradiation $\left(650 \mathrm{~nm} ; 39 \mathrm{~J} \cdot \mathrm{cm}^{-2}\right)$ during $20 \mathrm{~min}$. Two days after irradiation, MTT assay was performed to measure the level of living cells.

\subsection{Statistical Analysis}

Statistical analysis was performed using the Student's $t$-test to compare paired groups of data. A $p$ value $<0.05$ was considered as statistically significant.

\subsection{Singlet Oxygen Quantum Yield}

Absorption spectra were recorded on a UV-3600 UV-visible double beam spectrophotometer (SHIMADZU, Marne La Vallee, France). Fluorescence and singlet oxygen spectra were recorded on a Fluorolog FL3-222 spectrofluorimeter (HORIBA Jobin Yvon, LONGJUMEAU, Paris, France) equipped with $450 \mathrm{~W}$ Xenon lamp, a thermo-stated cell compartment $\left(25^{\circ} \mathrm{C}\right)$, a UV-visible photomultiplier R928 (Hamamatsu, Japan) and an InGaAs infrared detector (DSS-16A020L Electro-Optical System Inc., Phoenixville, PA, USA).

Excitation beam is diffracted by a double ruled grating SPEX monochromator (1200 grooves/mm blazed at $330 \mathrm{~nm}$ ). Emission beam is diffracted by a double ruled grating SPEX monochromator (1200 grooves $/ \mathrm{mm}$ blazed at $500 \mathrm{~nm}$ ). Singlet oxygen emission was detected through a double ruled grating SPEX monochromator (600 grooves $/ \mathrm{mm}$ blazed at $1 \mu \mathrm{m})$ and a long-wave pass $(780 \mathrm{~nm})$. All spectra were measured in 4 faces quartz cuves. All the emission spectra (fluorescence and singlet oxygen luminescence) have been displayed with the same absorbance (less than 0.2) with the lamp and photomultiplier correction. The standard used for the singlet oxygen quantum yield was the Zinc(II) 2,9,16,23-(tetra-t-butyl)phthalocyanine with a standard quantum yield of 0.25 .

\section{Conclusions}

Two new dyads $\mathbf{Z n P c - S n P h} \mathbf{Z}_{2}, \mathbf{Z n P c}-\mathrm{Sn}_{2} \mathbf{P h}_{\mathbf{6}}$ were prepared, by combining a zinc phthalocyanine sensitizer with a cytotoxic entity such as a tin-based complex. Cytotoxicity studies of the $\mathbf{Z n P c - S n P h} \mathbf{2}_{\mathbf{2}}$ and $\mathbf{Z n P c - S n _ { 2 }} \mathbf{P h}_{\mathbf{6}}$ dyads on cancer cells (MCF-7) and on healthy fibroblasts show that they exhibit high cytotoxicity. In particular, the dyad $\mathbf{Z n P c}-\mathbf{S n}_{\mathbf{2}} \mathbf{P h}_{\mathbf{6}}$ containing two tin atoms is highly potent towards cancer cells $\left(\mathrm{LC}_{50}=0.16 \mu \mathrm{M}\right)$ and is twice less toxic towards healthy human fibroblasts. In contrast, no PDT activity was detected for these two dyads at concentrations close to and below $\mathrm{LC}_{50}$, most probably due to quenching of the singlet excited state of phthalocyanine by the tin complex, which decreased the singlet oxygen quantum yield. This result highlights that for the development of conjugates consisting of a sensitizer connected to a chemotherapeutic agent, one must pay attention that the photophysical properties of the sensitizer and in particular its singlet oxygen quantum yield is maintained in the conjugate in order to combine the PDT activity with the cytotoxicity of the anticancer drug. This can be estimated from Stern-Volmer quenching experiments before synthesizing the conjugates. This aspect has been mostly overlooked in many previous studies dealing with similar approach.

Supplementary Materials: The following are available online at https://www.mdpi.com/article/ 10.3390/ph14050413/s1, Figure S1: UV-Vis. absorption spectra of compounds $\mathbf{S n P h}$ and $\mathbf{S n}_{\mathbf{2}} \mathbf{P h}_{\mathbf{6}}$ recorded in dichloromethane.; Figure S2: Mass spectrum of phthalocyanine 3; Figure S3: Mass spectrum of phthalocyanine 4; Figure S4: Mass spectrum of compound $\mathrm{ZnPcSnPh}_{2}$; Figure S5: Mass spectrum of compound $\mathbf{Z n P c S n}_{2} \mathbf{P h}_{6}$; Figure S6: ${ }^{1} \mathrm{H}$ NMR spectrum of phthalocyanine 3 recorded in $\mathrm{CDCl}_{3} ;$ Figure S7: ${ }^{1} \mathrm{H}$ NMR spectrum of phthalocyanine 4 recorded in DMSO- $\mathrm{d}_{6}$ with a trace of 
pyridine; Figure S8: ${ }^{1} \mathrm{H}$ NMR spectrum of compound $\mathbf{Z n P c - S n P h}$ recorded in THF-d 8 ; Figure S9: ${ }^{1} \mathrm{H}$ NMR spectrum of compound $\mathbf{Z n P c}-\mathbf{S n}_{2} \mathbf{P h}_{\mathbf{6}}$ recorded in DMSO-d $\mathrm{d}_{6}$ with a trace of pyridine.

Author Contributions: Synthesis of the compounds: I.T. and supervision S.D.; Biological studies: C.N., M.P., E.M. and supervisison M.G.-B.; singlet oxygen measurements: P.A. and supervision C.F.; Conceptualization: F.O., M.G.-B. and M.K. All authors have read and agreed to the published version of the manuscript.

Funding: This research was funded by Campus France (Eiffel grant), Région Pays de la Loire (LUMOMAT project), CNRS-L and the Lebanese University.

Institutional Review Board Statement: Not applicable.

Informed Consent Statement: Not applicable.

Data Availability Statement: Raw data is available from the corresponding author upon request.

Acknowledgments: We thank Campus France (Eiffel grant), Région Pays de la Loire (LUMOMAT project), CNRS-L and the Lebanese University for the financial support. The authors greatly acknowledge J. Hémez and L. Arzel (AMaCC platform, CEISAM UMR CNRS 6230, University of Nantes) for the mass spectrometry analyses. We thank Mélanie Onofre for technical assistance.

Conflicts of Interest: The authors declare no conflict of interest.

\section{References}

1. Karges, J.; Yempala, T.; Tharaud, M.; Gibson, D.; Gasser, G. A Multi-action and Multi-target RuII-PtIV Conjugate Combining Cancer-Activated Chemotherapy and Photodynamic Therapy to Overcome Drug Resistant Cancers. Angew. Chem. Int. Ed. 2020, 59, 7069-7075. [CrossRef]

2. Chen, Y.; Gao, Y.; Li, Y.; Wang, K.; Zhu, J. Synergistic chemo-photodynamic therapy mediated by light-activated ROS-degradable nanocarriers. J. Mater. Chem. B 2019, 7, 460-468. [CrossRef]

3. Zuluaga, F.M.; Lange, N. Combination of Photodynamic Therapy With Anti-Cancer Agents. Curr. Med. Chem. 2008, 15, 1655-1673. [CrossRef]

4. Li, X.; Lovell, J.F.; Yoon, J.; Chen, X. Clinical development and potential of photothermal and photodynamic therapies for cancer. Nat. Rev. Clin. Oncol. 2020, 17, 657-674. [CrossRef]

5. Li, X.; Lee, S.; Yoon, J. Supramolecular photosensitizers rejuvenate photodynamic therapy. Chem. Soc. Rev. 2018, 47, 1174-1188. [CrossRef]

6. Li, X.; Yu, S.; Lee, D.; Kim, G.; Lee, B.; Cho, Y.; Zheng, B.-Y.; Ke, M.-R.; Huang, J.-D.; Nam, K.T.; et al. Facile Supramolecular Approach to Nucleic-Acid-Driven Activatable Nanotheranostics That Overcome Drawbacks of Photodynamic Therapy. ACS Nano 2018, 12, 681-688. [CrossRef] [PubMed]

7. Lau, J.T.; Lo, P.C.; Fong, W.P.; Ng, D.K. A zinc(II) phthalocyanine conjugated with an oxaliplatin derivative for dual chemo- and photodynamic therapy. J. Med. Chem. 2012, 55, 5446-5454. [CrossRef] [PubMed]

8. Ryu, J.H.; Koo, H.; Sun, I.C.; Yuk, S.H.; Choi, K.; Kim, K.; Kwon, I.C. Tumor-targeting multi-functional nanoparticles for theragnosis: New paradigm for cancer therapy. Adv. Drug Deliv. Rev. 2012, 64, 1447-1458. [CrossRef] [PubMed]

9. Lottner, C.; Bart, K.C.; Bernhardt, G.; Brunner, H. Hematoporphyrin-Derived Soluble Porphyrin-Platinum Conjugates with Combined Cytotoxic and Phototoxic Antitumor Activity. J. Med. Chem. 2002, 45, 2064-2078. [CrossRef] [PubMed]

10. Lottner, C.; Bart, K.C.; Bernhardt, G.; Brunner, H. Soluble Tetraarylporphyrin-Platinum Conjugates as Cytotoxic and Phototoxic Antitumor Agents. J. Med. Chem. 2002, 45, 2079-2089. [CrossRef]

11. Chung Enhanced apoptotic effect of combined modality of 9-hydroxypheophorbide $\alpha$-mediated photodynamic therapy and carboplatin on AMC-HN-3 human head and neck cancer cells. Oncol. Rep. 1994, 21, 329-334.

12. Rizvi, I.; Celli, J.P.; Evans, C.L.; Abu-Yousif, A.O.; Muzikansky, A.; Pogue, B.W.; Finkelstein, D.; Hasan, T. Synergistic enhancement of carboplatin efficacy with photodynamic therapy in a three-dimensional model for micrometastatic ovarian cancer. Cancer Res. 2010, 70, 9319-9328. [CrossRef] [PubMed]

13. Kirveliene, V.; Grazeliene, G.; Dabkeviciene, D.; Micke, I.; Kirvelis, D.; Juodka, B.; Didziapetriene, J. Schedule-dependent interaction between Doxorubicin and MTHPC-mediated photodynamic therapy in murine hepatoma in vitro and in vivo. Cancer Chemother. Pharmacol. 2006, 57, 65-72. [CrossRef]

14. Aniogo, E.C.; George, B.P.A.; Abrahamse, H. In vitro combined effect of Doxorubicin and sulfonated zinc Phthalocyaninemediated photodynamic therapy on MCF-7 breast cancer cells. Tumour Biol. 2017, 39, 1010428317727278. [CrossRef] [PubMed]

15. Ali, S.; Muhammad, S.; Khurshid, A.; Ikram, M.; Maqsood, M.; Fisher, C.; Cathcart, J.; Lilge, L. Effective phthalocyanines mediated photodynamic therapy with doxorubicin or methotrexate combination therapy at sub-micromolar concentrations in vitro. Photodiagnosis Photodyn. Ther. 2018, 22, 51-64. [CrossRef]

16. Schmitt, F.; Govindaswamy, P.; Zava, O.; Suss-Fink, G.; Juillerat-Jeanneret, L.; Therrien, B. Combined arene ruthenium porphyrins as chemotherapeutics and photosensitizers for cancer therapy. J. Biol. Inorg. Chem. 2009, 14, 101-109. [CrossRef] 
17. Gianferrara, T.; Bergamo, A.; Bratsos, I.; Milani, B.; Spagnul, C.; Sava, G.; Alessio, E. Ruthenium-porphyrin conjugates with cytotoxic and phototoxic antitumor activity. J. Med. Chem. 2010, 53, 4678-4690. [CrossRef]

18. Ruiz-Gonzalez, R.; Milan, P.; Bresoli-Obach, R.; Stockert, J.C.; Villanueva, A.; Canete, M.; Nonell, S. Photodynamic Synergistic Effect of Pheophorbide a and Doxorubicin in Combined Treatment against Tumoral Cells. Cancers 2017, 9, 18. [CrossRef]

19. van Leeuwen, M.; Beeby, A.; Fernandes, I.; Ashworth, S.H. The photochemistry and photophysics of a series of alpha octa(alkylsubstituted) silicon, zinc and palladium phthalocyanines. Photochem. Photobiol. Sci. 2014, 13, 62-69. [CrossRef]

20. Liu, J.Y.; Lo, P.C.; Fong, W.P.; Ng, D.K. Effects of the number and position of the substituents on the in vitro photodynamic activities of glucosylated zinc(II) phthalocyanines. Org. Biomol. Chem. 2009, 7, 1583-1591. [CrossRef] [PubMed]

21. Zheng, B.-Y.; Zhang, H.-P.; Ke, M.-R.; Huang, J.-D. Synthesis and antifungal photodynamic activities of a series of novel zinc(II) phthalocyanines substituted with piperazinyl moieties. Dyes Pigment. 2013, 99, 185-191. [CrossRef]

22. Durmus, M.; Nyokong, T. Synthesis, photophysical and photochemical studies of new water-soluble indium(III) phthalocyanines. Photochem. Photobiol. Sci. 2007, 6, 659-668. [CrossRef] [PubMed]

23. Li, X.; Zheng, B.-D.; Peng, X.-H.; Li, S.-Z.; Ying, J.-W.; Zhao, Y.; Huang, J.-D.; Yoon, J. Phthalocyanines as medicinal photosensitizers: Developments in the last five years. Coord. Chem. Rev. 2019, 379, 147-160. [CrossRef]

24. Gómez-Ruiz, S.; Žižak, Ž.; Kaluđerović, G.N. Structural studies and cytotoxic activity against human cancer cell lines of mono and dinuclear tin(IV) complexes with the $\alpha, \alpha^{\prime}$-dimercapto-o-xylene ligand. Inorg. Chim. Acta 2014, 423, 117-122. [CrossRef]

25. Anjorin, C.; Song, X.; Kumar, D.; Pike, R.; De Dios, A.; Eng, G. Crystal structures of two polymeric bis(triphenyltin) malonates. J. Coord. Chem. 2010, 63, 4031-4040. [CrossRef]

26. Thorpe, D.; Callejas, A.; Royzman, D.; Pike, R.D.; Eng, G.; Song, X. Synthesis and crystal structures of ionic triphenyltin complexes with oxalic and malonic acid. J. Coord. Chem. 2013, 66, 3647-3659. [CrossRef]

27. Song, X.; Zapata, A.; Hoerner, J.; de Dios, A.C.; Casabianca, L.; Eng, G. Synthesis, larvicidal, QSAR and structural studies of some triorganotin 2,2,3,3-tetramethylcyclopropanecarboxylates. Appl. Organomet. Chem. 2007, 21, 545-550. [CrossRef]

28. Davies, A.G. 6-Tin. In Comprehensive Organometallic Chemistry II; Abel, E.W., Stone, F.G.A., Wilkinson, G., Eds.; Elsevier: Oxford, UK, 1995; pp. 217-303.

29. Foote, C.S.; Krasnovsky, A.A.; Fu, Y.; Selke, M.; Karney, W.L. Singlet Oxygen Dimol-Sensitized Luminescence and Reactions of Singlet Oxygen with Organometallics. In The Activation of Dioxygen and Homogeneous Catalytic Oxidation; Barton, D.H.R., Martell, A.E., Sawyer, D.T., Eds.; Springer: Boston, MA, USA, 1993; pp. 411-422.

30. Li, Y.; Wang, J.; Zhang, X.; Guo, W.; Li, F.; Yu, M.; Kong, X.; Wu, W.; Hong, Z. Highly water-soluble and tumor-targeted photosensitizers for photodynamic therapy. Org. Biomol. Chem. 2015, 13, 7681-7694. [CrossRef] 